J. Clin. Chem. Clin. Biochem.

Vol. 15,1977 , pp. $385-388$

\title{
A Simple, Rapid and Accurate Screening Test for Hyperchlororhoea
}

\author{
By L. Tomaszewski and L. Konarska
}

Medical School of Warsaw, Pharmaceutical Faculty, Institute of Biopharmacy, Department of Clinical Biochemistry, Warszawa, Poland

(Received September 1, 1976/January 17, 1977)

Summary: A simple, rapid screening paper test for the quantitative estimation of $\mathrm{Cl}^{-}$concentration in feces is described. The measured time of decolorisation of the Chlorotrex indicator by aqueous extract of feces is inversely proportional to the chloride concentration. The technical details of the test are given. The test is very suitable for laboratory and mass screening.

\section{Einfacher, schneller und genauer Screening-Test auf Hyperchlororhoe}

Zusammenfassung: Ein einfacher, schneller Papiertest für das Screening zur quantitativen Bestimmung von Chlorid in Faeces wird beschrieben. Die für die Entfärbung des Chlorotrex-Indikators durch wäßrige Extrakte von Faeces gemessene Zeit ist der Chloridkonzentration umgekehrt proportional. Technische Details des Tests werden angegeben. Der Test ist für Laboratoriums- und Massenscreening sehr geeignet.

\section{Introduction}

Congenital hypochloremic alkalosis wás discovered in children in 1945 simultaneously by two independent groups (Gamble (1) and Darrow (2)). These workers identified it as an inherited familial metabolic disease characterized by excessive fecal chloride excretion. Since the discovery of this defect, the number of reported cases both in children and adults $(3,4,5)$ has increased; the disease has been shown to have a regional distribution (6); and secondary chloride diarrhoea has been reported (7). A simple, widely applicable screening method for estimation of chloride in feces is therefore required. It is proposed that the determination of chloride in feces should be performed routinely in children born from the pregnancies accompanied by hydramnion, in infants with prolonged icterus, in cases of chronic diarrhoeas, in impaired somatic development of children and, of course, in clinically (8) obvious cases of congenital hypochloremic alkalosis.

During the last five years we made a biochemical study of five cases of chloride diarrhoea, four of which were in the region of Warsaw $(9-12)$. Such an accumulation of cases induced us to elaborate a method for measuring chloride in feces, which would be suitable for mass screening i. e. would be simple, rapid and readily applicable.
The principle of the method

$\mathrm{Ag}_{2} \mathrm{CrO}_{4}$ which is of a red brown colour forms with chloride ions a white precipitate of silver chloride. A piece of indicator filter paper soaked with $\mathrm{Ag}_{2} \mathrm{CrO}_{4}$, turns from brown to white when immersed in a solution containing chloride ions. The time of decolorisation of the indicator paper immersed in aqueous extract of feces is inversely proportional to the concentration of $\mathrm{Cl}^{-}$ions in the extract over a suitable range of $\mathrm{Cl}^{-}$ concentration.

The following chemical reactions are involved in the test:

I. The paper indicator preparation

$$
2 \mathrm{~K}^{+}+\mathrm{CrO}_{4}^{2-}+2 \mathrm{Ag}^{+}+2 \mathrm{NO}_{3}^{-}=\underset{\text { brown }}{\mathrm{Ag}_{2} \mathrm{CrO}_{4}}+2 \mathrm{~K}^{+}+2 \mathrm{NO}_{3}^{-}
$$

II. The reaction with chloride

$$
\begin{aligned}
\mathrm{Ag}_{2} \mathrm{CrO}_{4}+2 \mathrm{Cl}^{-}= & 2 \mathrm{AgCl}+\mathrm{CrO}_{4}^{2-} \\
& \text { white light yellow }
\end{aligned}
$$

The time of decolorisation of Chlorotrex depends on the properly chosen concentrations of reagents. 


\section{Material and Methods}

\section{Reagents}

1. $0.25 \mathrm{~mol} / \mathrm{AgNO}_{3}$. Weigh $4.25 \mathrm{~g}$ of $\mathrm{AgNO}_{3}$ into the $100 \mathrm{ml}$ volumetric flask, fill with distilled water up to the mark. Mix well. Keep in darkness. Before use dilute one part of solution with 6 parts of distilled water.

2. $25 \mathrm{~g} / \mathrm{I} \mathrm{K}_{2} \mathrm{CrO}_{4}$. Before use dilute one part of solution with 6 parts of distilled water.

3. The stock standard solution of $\mathrm{NaCl} 100 \mathrm{mmol} / 1$. Weigh $0.581 \mathrm{~g}$ of $\mathrm{NaCl}$ dried to a stable weight at $110^{\circ} \mathrm{C}$ into a $100 \mathrm{ml}$ volumetric flask. Dilute to the mark.

4. Preparation of Chlorotrex indicator. The indicator is prepared by dipping the strips of Whatman chromatography paper No 1 in suitable solutions of $\mathrm{K}_{2} \mathrm{CrO}_{4}$ and $\mathrm{AgNO}_{3}$. The strips are then dried, cut into small squares $(5 \times 5 \mathrm{~mm})$ and kept in darkness.

\section{The extract of feces}

For this purpose put $2 \mathrm{ml}$ of deionized water into a conical centrifuge tube, fill with feces to $2.5 \mathrm{ml}$ and centrifuge at a speed and for a time sufficient to obtain a clear supernatant. By using these proportions the test is performed on the supernatant from fivefold diluted feces.

\section{Calibration curve for Chlorotrex}

From the stock standard solutions of $\mathrm{NaCl}$ prepare working solutions with concentrations ranging from 5 to $75 \mathrm{mmol} / 1$ by diluting with deionized water $0.5 \quad 1.02 .02 .5 \quad 5.07 .5$ and $10 \mathrm{ml}$ of stock standard solution up to $100 \mathrm{ml}$. Transfer 0.5 $\mathrm{ml}$ (about 10 drops) of each working solution to a small pit of a plate and dip into it a single square of Chlorotrex; simultaneously start the stop-clock and measure the time of decolorisation. An example of the calibration curve is presented in figure 1.

The calibration curve is well reproducible with different Chlorotrex strips prepared with different batches of the de novo prepared reagents (which we call "charges")

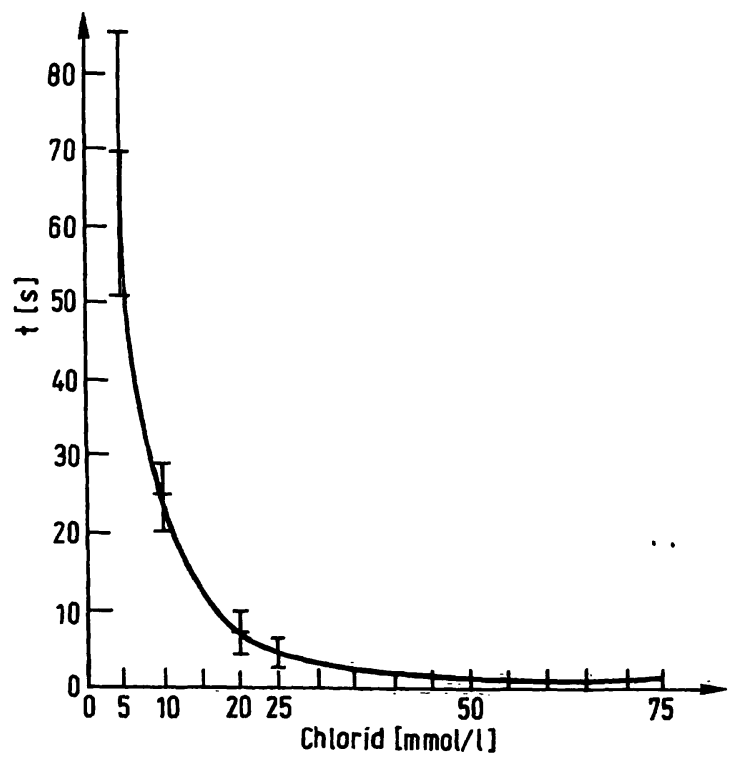

Fig. 1. The calibration curve performed on different charges of Chlorotrex.

\section{Results}

\section{The performance of the test}

Into a small pit of a plate with capacity of ca. $1.0 \mathrm{ml}$ pour about $0.5 \mathrm{ml}$ of clear aqueous supernatant of centrifuged feces. Introduce Chlorotrex into supernatant, start the stop-clock and measure the time of decolorisation with constant shaking of the plate. Read the concentration of $\mathrm{Cl}^{-}$from calibration curve, multiplying the result by 5 (dilution). The shaking of the plate exerts some influence in the range of lowest chloride values, i. e. normal ones. At higher, pathological concentrations its influence is insignificant.

The reproducibility of results obtained with Chlorotrex prepared from different strips and with different charges

The time of decolorisation decreases over the concentration range $5 \mathrm{mmol} / 1-75 \mathrm{mmol} / 1$, from 70 seconds (range $52-87 \mathrm{mmol} / \mathrm{l}$ ) to 0.3 second (fig. 1).

The greatest differences in decolorisation time both between individual strips and separate charges appear at the lowest concentration of $\mathrm{Cl}^{-}(5 \mathrm{mmol} / \mathrm{l})$. From the diagnostic point of view this concentration is unimportant.

\section{Accuracy}

The accuracy of the Chlorotrex indicator was controlled by the classical chemical method of ShalesShales (13) by recovery experiments on different kinds of feces. The results on meconium are presented in table 1.

Similar results were obtained on feces of children and adults. The recoveries of $\mathrm{Cl}^{-}$in meconium and stools of children, both fresh and frozen, determined with Chlorotrex and checked by classical method were very satisfactory. The recoveries were unsatisfactory only in the case of feces of adults kept in the frozen state. The extracts became turbid, dark and viscid. The reasons for this phenomenon are unknown.

\section{The storäge of samples}

There arises a practical question: for how many days can feces be kept prior to the examination without changes in the chloride concentration? We have proved that the feces of children, irrespective whether they contain chloride at low or high concentration, can be safely kept up to five days at room temperature without marked loss. From another point of view they can be transported to the laboratory even by ordinary mail. The same results were obtained with samples kept in the refrigerator.

\section{The homogeneity of chloride distribution in feces}

The samples were taken from more than 10 different parts of the formed feces of several children, each with a 
Tab. 1. The accuracy of determination of $\mathrm{Cl}^{-}$in meconium with Chlorotrex checked by recovery experiments and rechecked with the classical chemical method.

\begin{tabular}{|c|c|c|c|c|c|}
\hline Sample & $\begin{array}{l}\text { Chloride } \\
\text { theo- } \\
\text { retical } \\
\text { valuc } \\
|\mathrm{mmol} / 1|^{\mathrm{a}}\end{array}$ & $\begin{array}{l}\text { Chloride } \\
\text { deter- } \\
\text { mined } \\
\text { by } \\
\text { Schales- } \\
\text { Schales } \\
\text { method } \\
\text { | mmol/1] }\end{array}$ & $\begin{array}{l}\text { Recovery } \\
\text { by } \\
\text { Schales. } \\
\text { Schales } \\
|\%|\end{array}$ & $\begin{array}{l}\text { Chloride } \\
\text { deter- } \\
\text { mined } \\
\text { with } \\
\text { Chloro- } \\
\text { trex } \\
\text { [mmol/l] }\end{array}$ & $\begin{array}{l}\text { Recovery } \\
\text { with } \\
\text { Chloro- } \\
\text { trex } \\
\\
|\%|\end{array}$ \\
\hline 1 & 2 & 3 & 4 & 5 & 6 \\
\hline 1 & $\begin{array}{l}82.7 \\
42.7\end{array}$ & $\begin{array}{l}80.0 \\
40.0\end{array}$ & $\begin{array}{l}96.7 \\
93.7\end{array}$ & $\begin{array}{l}75.0 \\
42.5\end{array}$ & $\begin{array}{l}90.7 \\
99.5\end{array}$ \\
\hline 2 & $\begin{array}{l}81.6 \\
41.6\end{array}$ & $\begin{array}{l}81.2 \\
41.6\end{array}$ & $\begin{array}{r}99.6 \\
100.0\end{array}$ & $\begin{array}{l}75.0 \\
42.5\end{array}$ & $\begin{array}{r}91.9 \\
102.1\end{array}$ \\
\hline 3 & $\begin{array}{l}81.0 \\
41.0\end{array}$ & $\begin{array}{l}76.7 \\
37.3\end{array}$ & $\begin{array}{l}95.0 \\
91.2\end{array}$ & $\begin{array}{l}75.0 \\
42.5\end{array}$ & $\begin{array}{r}91.5 \\
103.6\end{array}$ \\
\hline 4 & $\begin{array}{l}82.0 \\
42.0\end{array}$ & $\begin{array}{l}82.4 \\
41.7\end{array}$ & $\begin{array}{r}100.3 \\
99.0\end{array}$ & $\begin{array}{l}75.0 \\
45.0\end{array}$ & $\begin{array}{r}91.5 \\
107.1\end{array}$ \\
\hline 5 & $\begin{array}{l}81.2 \\
41.2\end{array}$ & $\begin{array}{l}84.0 \\
40.0\end{array}$ & $\begin{array}{l}99.0 \\
97.0\end{array}$ & $\begin{array}{l}75.0 \\
42.0\end{array}$ & $\begin{array}{r}92.4 \\
101.9\end{array}$ \\
\hline 6 & $\begin{array}{l}31.6 \\
21.6\end{array}$ & $\begin{array}{l}35.3 \\
23.5\end{array}$ & $\begin{array}{l}111.8 \\
109.0\end{array}$ & $\begin{array}{l}33.0 \\
22.0\end{array}$ & $\begin{array}{l}104.4 \\
101.8\end{array}$ \\
\hline 7 & $\begin{array}{l}31.6 \\
21.6\end{array}$ & $\begin{array}{l}35.7 \\
23.9\end{array}$ & $\begin{array}{l}113.0 \\
110.9\end{array}$ & $\begin{array}{l}35.5 \\
24.0\end{array}$ & $\begin{array}{l}112.3 \\
111.1\end{array}$ \\
\hline 8 & $\begin{array}{l}31.9 \\
21.9\end{array}$ & $\begin{array}{l}37.3 \\
25.1\end{array}$ & $\begin{array}{l}110.2 \\
114.2\end{array}$ & $\begin{array}{l}37.5 \\
23.0\end{array}$ & $\begin{array}{l}117.5 \\
105.0\end{array}$ \\
\hline 9 & $\begin{array}{l}31.2 \\
21.2\end{array}$ & $\begin{array}{l}34.5 \\
23.1\end{array}$ & $\begin{array}{l}110.6 \\
109.2\end{array}$ & $\begin{array}{l}39.0 \\
24.0\end{array}$ & $\begin{array}{l}125.0 \\
113.2\end{array}$ \\
\hline 10 & $\begin{array}{l}33.5 \\
23.5\end{array}$ & $\begin{array}{l}33.7 \\
21.9\end{array}$ & $\begin{array}{r}100.5 \\
93.4\end{array}$ & $\begin{array}{l}35.0 \\
23.0\end{array}$ & $\begin{array}{r}104.4 \\
97.8\end{array}$ \\
\hline
\end{tabular}

a) To the samples of meconium with determined $\mathrm{Cl}^{-}$concentration (Schales-Schales) various amounts of standard solution of $\mathrm{NaCl}$ were added.

Tab. 2. Fecal chloride concentration in normal children. The determinations were performed with the classical method of Schales-Schales. All cases are "Chlorotrex negative".

\begin{tabular}{llcl}
\hline $\begin{array}{l}\text { Age in } \\
\text { months }\end{array}$ & $\begin{array}{l}\text { Number } \\
\text { of cases }\end{array}$ & $\begin{array}{l}\text { Mean chloride } \\
\text { concentration } \\
\text { [mmol/1] }\end{array}$ & $\begin{array}{l}\text { Range } \\
\text { [mmol/1] }\end{array}$ \\
\hline 8 & 14 & 12.02 & $6.1-16.0$ \\
9 & 11 & 7.8 & $3.0-9.6$ \\
10 & 11 & 6.2 & $3.7-8.6$ \\
12 & 26 & 10.14 & $2.0-19.0$ \\
15 & 14 & 12.01 & $5.3-18.0$ \\
\hline
\end{tabular}

normal chloride content. At the mean of $15.7 \mathrm{mmol} / \mathrm{l}$ we ob tained a mean standard deviation 1.02 (range $0.46-0.92) \mathrm{mmol} / \mathrm{l}$ and a mean coefficient of variation at $7 \%$ (range $6.08-8.29 \%$ ).

Practically no differences in chloride content were observed. One sample is representative for the whole content of the chamberpot.

\section{Normal range}

The chloride concentration in feces of children examined over several days showed no marked changes.
Tab. 3. Determination of $\mathrm{Cl}^{-}$concentration by two methods in feces of children with hyperchlororhoea. From the statistic point of vicw these methods are hardly comparable. One method is precise, the second semiquantitative. Relatively small clinically unimportant deviations cause significant differences at these mean values.

\begin{tabular}{rrllc}
\hline $\begin{array}{l}\text { Num- Age } \\
\text { ber of in } \\
\text { case } \\
\text { months }\end{array}$ & Diagnosis & $\begin{array}{l}\mathrm{Cl}^{-} \text {concen- } \\
\text { tration by } \\
\text { classical } \\
\text { method } \\
\text { [mmol/1] }\end{array}$ & $\begin{array}{l}\mathrm{Cl}^{-} \text {concen- } \\
\text { tration with } \\
\text { Chlorotrex }\end{array}$ \\
& & & [mmol/1] \\
\hline 11 & 10 & Colitis, pulmonitis & 58.8 & 59.0 \\
30 & 1 & Colitis, pulmonitis & 98.0 & 100.0 \\
33 & 5 & Colitis, E. coli & 37.2 & 44.0 \\
35 & 6 & Colitis, pulmonitis & 52.9 & 55.0 \\
40 & 6 & Colitis, pulmonitis & 47.0 & 50.0 \\
43 & 3 & Colitis, pulmonitis & 52.9 & 47.5 \\
99 & 5 & Colitis & 51.0 & 50.0 \\
117 & 3 & Colitis & 40.0 & 48.0 \\
121 & 4 & Angina, tetania & 43,2 & 48.0 \\
124 & 6 & Colitis acuta & 56.9 & 60.0 \\
126 & 14 & Colitis & 66.7 & 70.0 \\
128 & 2 & Colitis, pulmonitis & 64.7 & 72.0 \\
130 & 2 & Colitis, pulmonitis & 43.2 & 47.0 \\
\hline \multicolumn{5}{c}{$\bar{x}$} \\
\end{tabular}

The normal range of chloride concentration in feces of heal thy children up to 15 months of age does not exceed $20 \mathrm{mmol} / 1$ (tab. 2). In these cases Chlorotrex always gives a negative result.

The mean chloride concentration in the meconium of healthy newborns determined with the classical method on 30 samples is $8.3 \mathrm{mmol} / \mathrm{l}$ with the range $3.9-13.7$ $\mathrm{mmol} / \mathrm{l}$. Chlorotrex is always negative for this range.

\section{Chlorotrex "minus - negative" and chlorotrex "plus - positive" cases in hospitalized children}

As the borderline value between the normal and increased (pathological?) $\mathrm{Cl}^{-}$concentrations in feces we have accepted $30 \mathrm{mmol} / \mathrm{l}(14)$, which corresponds to a decolorisation time greater than 40 seconds. The stools with $\mathrm{Cl}^{-}$concentrations higher than $30 \mathrm{mmol} / 1$ were designated as "chlorotrex plus" (+). These showed a decolorisation time shorter than 40 seconds.

In the group of 130 hospitalized children we have found 13 chlorotrex positive cases. The results of simultaneous determinations by the classical chemical method in Chlorotrex $(+)$ cases are presented in table 3.

\section{Discussion}

As far as we know, no attemps have been made to elaborate a screening test for chloride concentration in feces, and apparently there was no need for such a method. Now the situation is changed. The hitherto almost unexplored physiopathology of electrolyte exchange in the gut has become a broad and interesting field of study. 
The proposed method seems to be a very useful laboratory 3. The samples of feces can be kept up to five days test for performing mass screening as well as laboratory screening of the material coming to the laboratory, allowing the separation of those samples in which the $\mathrm{Cl}^{-}$concentration is normal and which can be rejected, from those with elevated $\mathrm{Cl}^{-}$concentration which have to be submitted to quantitative measurements. When measuring the concentration of $\mathrm{Cl}^{-}$in feces one precaution must be carefully observed, irrespective of the method used: the concentration of $\mathrm{Cl}^{-}$in urine is normally at last five times as high as in feces, and it is variable; the feces must therefore be collected carefully, to avoid contamination with urine, which invalidates the interpretation of the results.

It is very interesting that there is a rather high incidence of hyperchlororhoea in small hospitalized infants.

\section{Conclusions}

1. The results obtained with Chlorotrex are very consistent with the determination of $\mathrm{Cl}^{-}$concentration in feces by the classical method, especially at higher, pathological concentrations.

2. The chloride excretion in normal children is stable over several days.

\section{References}

1. Gamble, J. L., Fahey, K. R., Appleton, J. \& Mac Lachan, E. (1945), J. Ped. 26, 509-518

2. Darrow, D. C. (1945), J. Ped. 26, 519-532.

3. Gorden, P. \& Levitin, M. (1973), Ann. Intern. Med. 78 , 876-882.

4. Davidson, A. G. F., Insley, J., Caps, F. P. A. \& Anderson, C. M. (1970), Aust. Paed. J. 8, 187-190.

5. Ariel, I. M. (1954), Arch. Surg. 68, 105-116.

6. Nordio, R., Perheentupa, J., Launiala, K. \& Hallman, N. (1971) Clin. Genet. 2, 182-192.

7. Aaronson, J. (1971), Arch. Dis. Childh. 46, 479-483.

8. Michalsen, H. (1972), Acta Paed. Scand. 61, 615-618. at room temperature or in a refrigerator prior to examination without change in the $\mathrm{Cl}^{-}$concentration.

4. In the case of adults, Chlorotrex can be applied for the determination of $\mathrm{Cl}^{-}$concentration only in fresh stools, and cannot be applied to stored material, even if it is kept in refrigerator.

5. The concentration of $\mathrm{Cl}^{-}$in meconium does not exceed $14 \mathrm{mmol} / \mathrm{l}$.

6. In children up to two years old the $\mathrm{Cl}^{-}$concentration in feces is in the range $8 \mathrm{mmol} / \mathrm{l}-24 \mathrm{mmol} / \mathrm{l}$.

7. Chlorotrex is a test fully suitable for laboratory screening and epidemiological mass screening for detection of chloride diarrhoea, its heterozygotic forms or secondary diarrhoeas.

\section{Acknowledgement}

We gratefully acknowledge the skilfull assistance of Miss A. Dybowska.

This work was supported by the Department of Medical Sciences of Polish Academy of Sciences No. 494/VI, 1976

9. Hager-Matecka, B., Śliwa, F. \& Fronczak, F. (1971), Pol. Tyg. Lek. 26, 829-831.

10. Foltańska, H. (1971), Ped. Pol. 46, 1405-1408.

11. Sieniawska, M., Kawalec, W., Korniszewska, J. \& Tołtoczko, J. (1975), Ped. Pol. 50, 83-86.

12. Tomaszewski, L. Not yet published three cases.

13. Schales, O. \& Schales, S. (1941), J. Biōl. Chem. 140, 879-884.

14. Maksymowicz, M., Torbicka, E., Moniuk, O. \& Tomaszewski, L. (1974), Pol. Med. Sc. History Bullet. 15/II, 399-406.
Doc. dr hab. med. L. Tomaszewski Department of Clinical Biochemistry Institute of Biopharmacy Medical Academy ul. Banacha 1 PL-02 097 Warsaw 